\title{
Effects of dietary starch content and rate of fermentation on methane production in lactating dairy cows
}

\author{
B. Hatew, ${ }^{* 1}$ S. C. Podesta, ${ }^{*}$ H. Van Laar, ${ }^{\star} †$ W. F. Pellikaan, ${ }^{*}$ J. L. Ellis, ${ }^{*} \ddagger$ J. Dijkstra, ${ }^{*}$ and A. Bannink§ \\ *Animal Nutrition Group, Wageningen University, PO Box 338, 6700 AH Wageningen, the Netherlands \\ †Nutreco R\&D, PO Box 220, 5830 AE Boxmeer, the Netherlands \\ $\ddagger$ Centre for Nutrition Modeling, Department of Animal and Poultry Science, University of Guelph, Guelph, ON, N1G 2W1, Canada \\ §Animal Nutrition, Wageningen UR Livestock Research, PO Box 65, Lelystad, the Netherlands
}

\begin{abstract}
The objective of this study was to investigate the effects of starch varying in rate of fermentation and level of inclusion in the diet in exchange for fiber on methane $\left(\mathrm{CH}_{4}\right)$ production of dairy cows. Forty Holstein-Friesian lactating dairy cows of which 16 were rumen cannulated were grouped in 10 blocks of 4 cows each. Cows received diets consisting of $60 \%$ grass silage and $40 \%$ concentrate (dry matter basis). Cows within block were randomly assigned to 1 of 4 different diets composed of concentrates that varied in rate of starch fermentation [slowly (S) vs. rapidly (R) rumen fermentable; native vs. gelatinized corn grain] and level of starch (low vs. high; 270 vs. $530 \mathrm{~g} / \mathrm{kg}$ of concentrate dry matter). Results of rumen in situ incubations confirmed that the fractional rate of degradation of starch was higher for $\mathrm{R}$ than S starch. Effective rumen degradability of organic matter was higher for high than low starch and also higher for R than S starch. Increased level of starch, but not starch fermentability, decreased dry matter intake and daily $\mathrm{CH}_{4}$ production. Milk yield (mean 24.0 $\pm 1.02 \mathrm{~kg} / \mathrm{d}$ ), milk fat content (mean $5.05 \pm 0.16 \%$ ), and milk protein content (mean $3.64 \pm 0.05 \%$ ) did not differ between diets. Methane expressed per kilogram of fat- and protein-corrected milk, per kilogram of dry matter intake, or as a fraction of gross energy intake did not differ between diets. Methane expressed per kilogram of estimated rumen-fermentable organic matter (eRFOM) was higher for $\mathrm{S}$ than $\mathrm{R}$ starch-based diets (47.4 vs. $42.6 \mathrm{~g} / \mathrm{kg}$ of eRFOM) and for low than high starch-based diets (46.9 vs. $43.1 \mathrm{~g} / \mathrm{kg}$ of eRFOM). Apparent total-tract digestibility of neutral detergent fiber and crude protein were not affected by diets, but starch digestibility was higher for diets based on $\mathrm{R}$ starch (97.2\%) compared with S starch (95.5\%). Both total volatile fatty acid concentration (109.2 vs. 97.5 $\mathrm{m} M$ ) and propionate proportion (16.5 vs. $15.8 \mathrm{~mol} / 100$
\end{abstract}

Received May 30, 2014.

Accepted September 24, 2014.

${ }^{1}$ Corresponding author: bayissa.chuko@wur.nl mol) were higher for $\mathrm{R}$ starch- compared with $\mathrm{S}$ starch-based diets but unaffected by the level of starch. Total $\mathrm{N}$ excretion in feces plus urine and $\mathrm{N}$ retained were unaffected by dietary treatments, and similarly energy intake and output of energy in milk expressed per unit of metabolic body weight were not affected by treatments. In conclusion, an increased rate of starch fermentation and increased level of starch in the diet of dairy cattle reduced $\mathrm{CH}_{4}$ produced per unit of eRFOM but did not affect $\mathrm{CH}_{4}$ production per unit of feed dry matter intake or per unit of milk produced.

Key words: methane, starch fermentability, starch level, dairy cow

\section{INTRODUCTION}

Starch is a major source of glucogenic energy for high-yielding dairy cows and a source of fermentable energy for rumen microorganisms (Koenig et al., 2003). In addition to carbon dioxide, microbial matter, and VFA production, fermentation of feeds in the rumen results in release of hydrogen, which is used by methanogenic archaea to reduce carbon dioxide and produce methane, a potent greenhouse gas that has 25 times more global-warming potential than carbon dioxide (IPCC, 2007). The production of methane $\left(\mathrm{CH}_{4}\right)$ is influenced by dietary factors, such as type and amount of feed, and various dietary strategies have been suggested to reduce enteric $\mathrm{CH}_{4}$ production (Hristov et al., 2013; Knapp et al., 2014). Compared with dietary fiber, starch fermentation in the rumen may result in reduced enteric $\mathrm{CH}_{4}$ production because fermentation of starch favors production of propionate (Bannink et al., 2006), creating an alternative hydrogen sink to methanogenesis. Moreover, unlike fiber and sugar, a substantial fraction of potentially fermentable starch may escape from rumen fermentation to be digested enzymatically in the small intestine, adding to the energy supply of the animal without associated losses of energy with $\mathrm{CH}_{4}$ production (Dijkstra et al., 2011).

The use of starch versus fiber as well as increasing dietary starch content in the concentrate are potential 
options to reduce ruminal $\mathrm{CH}_{4}$ production, relative to total energy supply to the animal (Hristov et al., 2013). Using a modeling approach, Benchaar et al. (2001) estimated that the use of less ruminally fermentable starch and replacing fibrous concentrate with starchy concentrate reduces $\mathrm{CH}_{4}$ emissions by 17 and $22 \%$ in ruminants, respectively. Compared with rapidly fermentable starch sources such as barley or wheat, the use of a slowly fermentable starch such as corn may result in a reduction of $\mathrm{CH}_{4}$ production (Mills et al., 1999, 2001), mainly attributed to a shift in starch digestion from the rumen to the small intestine. Similarly, the substitution of sugar in the concentrate with a rapidly fermentable starch source such as barley or wheat was estimated to reduce $\mathrm{CH}_{4}$ production in ruminants (Mills et al., 2001), due to lower ratio of acetate and butyrate to propionate production from starch fermentation (Benchaar et al., 2001; Mills et al., 2001) and the subsequent increase in ME supply to the dairy cow (Mills et al., 2001). However, increasing the amount of rapidly fermentable starch in the diet at the expense of forage fiber can increase the production of VFA beyond the buffering and absorptive capacity of the rumen, leading to a decreased ruminal $\mathrm{pH}$ that has negative consequences on fiber degradation and production of dairy cows (Dijkstra et al., 2012). Moreover, the level of abatement of enteric $\mathrm{CH}_{4}$ production achievable in dairy cattle with grass silage-based diets in which sources and levels of starch in the concentrate vary is largely lacking.

The objective of this study was to evaluate the effects of starch varying in rate of fermentation and in level of inclusion in concentrate that accounted for $40 \%$ of the TMR DM on $\mathrm{CH}_{4}$ production of dairy cows. We hypothesized that increasing the inclusion of ruminally fermentable starch in the diet at the expense of fiber enhances propionate production, and that decreasing rate of fermentation of the starch in the rumen shifts starch digestion from the rumen to the small intestine, both expected to decrease $\mathrm{CH}_{4}$ production expressed per unit of feed or milk.

\section{MATERIALS AND METHODS}

This experiment was conducted as a complete randomized block design at the animal research facility of Wageningen University (Wageningen, the Netherlands). All experimental procedures were approved by the Institutional Animal Care and Use Committee of Wageningen University and carried out under the Dutch Law on Animal Experimentation.

\section{Cows, Experimental Design, and Diets}

Forty multiparous lactating Holstein-Friesian dairy cows were selected and grouped in 10 blocks based on parity $(2.9 \pm 1.1$; mean \pm SD), DIM $(215 \pm 89 \mathrm{~d})$, fatand protein-corrected milk (FPCM; $35.9 \pm 9.5 \mathrm{~kg} / \mathrm{d}$ ) at the start of the experiment, and presence or absence of rumen cannula. Sixteen cows were rumen cannulated and used to evaluate the effects of dietary treatments on rumen fermentation characteristics $(\mathrm{pH}$ and VFA concentration). Cows within a block were randomly assigned to 1 of 4 dietary treatments. Treatments were 1) $270 \mathrm{~g}$ of slowly fermentable starch per kilogram of concentrate DM, 2) $530 \mathrm{~g}$ of slowly fermentable starch per kilogram of concentrate DM, 3) $270 \mathrm{~g}$ of rapidly fermentable starch per kilogram of concentrate DM, and 4) $530 \mathrm{~g}$ of rapidly fermentable starch per kilogram of concentrate DM. Cows were fed a total mixed diet composed of grass silage and concentrate mixed at a 60:40 ratio (DM basis). Diets were offered individually and in equal portions during a.m. and p.m. (0600 and $1600 \mathrm{~h}$ ) feedings. The concentrates were in meal form and mixed with the forage portion manually when fed.

The primary starch sources in the concentrate were native corn grain, which is slowly fermentable $(\mathbf{S})$, and gelatinized corn grain, which is rapidly fermentable $(\mathbf{R})$, and each source was included at 2 levels: a low (L, $270 \mathrm{~g}$ of starch $/ \mathrm{kg}$ of concentrate DM) and a high $(\mathbf{H}$, $530 \mathrm{~g}$ of starch $/ \mathrm{kg}$ of concentrate DM) level. Increasing the level of starch in concentrate was achieved by exchanging either ground native corn grain or ground gelatinized corn grain with beet pulp and palm kernel expeller on DM basis. The ingredient composition of the concentrates is shown in Table 1. Both native and gelatinized corn grain were obtained from a single batch of corn. These 2 starch sources were chosen to create a large difference in rate of starch fermentation.

The experiment was conducted in 10 successive periods of $17 \mathrm{~d}$ each. In each period cows were individually housed in tie-stalls for $12 \mathrm{~d}$ as an adaptation period and to determine individual daily feed intake. Diets were supplied ad libitum for the first $8 \mathrm{~d}$ in the tie-stalls (approximately at $110 \%$ of expected voluntary intake). From d 9 to 17, feed intake was restricted per block to $95 \%$ of the ad libitum feed intake of the animal consuming the lowest amount of feed during d 3 to 8 within a block to avoid the potential confounding effect of feed intake level on $\mathrm{CH}_{4}$ measurements. After the end of the adaptation period, cows were housed for $5 \mathrm{~d}$ in 1 of the 2 identical climate-controlled respiration chambers for the measurement of $\mathrm{CH}_{4}$ production. In addition, digestibility measurements and a complete $\mathrm{N}$ and energy balance were performed. Because 2 chambers were available, measurements were obtained in 10 periods, staggered in time in an incomplete randomized block design, as described previously by Van Zijderveld et al. (2011a). Within each period, 2 cows receiving the same treatment were housed in one chamber, and 2 cows re- 
Table 1. Ingredients and nutrient composition $(\mathrm{g} / \mathrm{kg}$ of $\mathrm{DM}$, unless otherwise stated) of concentrates fed during the experiment

\begin{tabular}{|c|c|c|c|c|}
\hline \multirow[b]{2}{*}{ Item } & \multicolumn{2}{|c|}{ Slowly fermentable } & \multicolumn{2}{|c|}{ Rapidly fermentable } \\
\hline & Low level & High level & Low level & High level \\
\hline \multicolumn{5}{|l|}{ Ingredient } \\
\hline Native corn grain & 412.9 & 816.1 & - & - \\
\hline Gelatinized corn grain & - & - & 412.9 & 816.1 \\
\hline Palm kernel expeller & 266.8 & 119.8 & 266.8 & 119.8 \\
\hline Beet pulp (low sugar) & 282.7 & — & 282.7 & — \\
\hline Soybean meal & 18.7 & - & 18.7 & - \\
\hline Soybean meal, formaldehyde treated & - & 13.5 & - & 13.5 \\
\hline Urea & 13.5 & 23.4 & 13.5 & 23.4 \\
\hline Limestone & 0.9 & 14.0 & 0.9 & 14.0 \\
\hline Magnesium oxide & - & 5.0 & - & 5.0 \\
\hline Salt & 3.1 & 3.7 & 3.1 & 3.7 \\
\hline Sodium bicarbonate & - & 2.5 & - & 2.5 \\
\hline Vitamin-mineral premix $^{1}$ & 1.5 & 1.5 & 1.5 & 1.5 \\
\hline \multicolumn{5}{|l|}{ Nutrient composition } \\
\hline $\mathrm{DM}$ ( $\mathrm{g} / \mathrm{kg}$ of product as fed) & 884 & 889 & 887 & 882 \\
\hline Ash & 54 & 50 & 47 & 48 \\
\hline $\mathrm{CP}$ & 169 & 170 & 167 & 186 \\
\hline $\mathrm{NDF}$ & 311 & 170 & 308 & 153 \\
\hline $\mathrm{ADF}$ & 187 & 90 & 181 & 80 \\
\hline $\mathrm{ADL}$ & 41 & 21 & 41 & 23 \\
\hline Crude fat & 43 & 34 & 47 & 41 \\
\hline Starch & 275 & 518 & 303 & 542 \\
\hline Sugar & 36 & 22 & 33 & 22 \\
\hline Gross energy (MJ/kg of DM) & 18.5 & 18.4 & 18.7 & 18.3 \\
\hline
\end{tabular}

${ }^{1}$ Contained per kilogram of premix: 4,000,000 IU of vitamin A; 833,000 IU of vitamin D; 10,000 mg of vitamin $\mathrm{E} ; 10,000 \mathrm{mg}$ of $\mathrm{Cu} ; 23,333 \mathrm{mg}$ of Zn; 18,467 mg of Mn; $500 \mathrm{mg}$ of Co; $667 \mathrm{mg}$ of I, and $200 \mathrm{mg}$ of Se.

ceiving a different treatment were housed in the other chamber. Within each chamber, the 2 cows originated from different blocks and each dietary treatment was not paired with the other dietary treatments in equal number of periods. The experimental unit for data measured in the respiration chambers (in particular gaseous exchange, $\mathrm{N}$ and energy balance parameters) therefore consisted of a pair of cows. The respiration chambers have been described in detail by Verstegen et al. (1987) and Van Zijderveld et al. (2011b). Cows had free access to drinking water throughout the experiment.

\section{Ruminal $\mathrm{pH}$ and Concentration of VFA}

On d 10 and 11 of each experimental period, equal volumes of rumen fluid from rumen-cannulated cows were collected to determine rumen $\mathrm{pH}$ and VFA concentration. Rumen fluid for each cow was collected from the front ventral, middle ventral, and cranial dorsal sac of the rumen (Abrahamse et al., 2008) at 0 (just before the $0600 \mathrm{~h}$ feeding), 1, 2, 3, 4, 6, and $8 \mathrm{~h}$ after a.m. feeding. Rumen fluid was collected by suction method using a solid plastic tube $(0.85 \mathrm{~m}$ long and $2.5 \mathrm{~cm}$ in diameter) perforated at the end. Ruminal $\mathrm{pH}$ was determined immediately after sampling using a portable pH meter (Hanna Instruments Model HI 9024, IJsselstein, the Netherlands). A subsample $(0.75 \mathrm{~mL})$ of ruminal fluid was mixed with an equal volume of meta-phosphoric acid and immediately stored at $-20^{\circ} \mathrm{C}$ pending VFA analysis.

\section{Feed Intake, Nutrients Digestibility, Nitrogen and Energy Balance}

Samples of grass silage and concentrates were collected when feeds were prepared. During the $\mathrm{CH}_{4}$ measurement period, orts (when present) were weighed daily and stored at $4^{\circ} \mathrm{C}$. At the end of each period, daily orts were composited per cow and mixed and a subsample was retained and stored at $-20^{\circ} \mathrm{C}$. Apparent total-tract digestibility of nutrients was determined using chromium oxide $\left(\mathrm{Cr}_{2} \mathrm{O}_{3}\right)$ as an external marker included in the concentrate. The marker $(1.5 \mathrm{~g}$ of $\mathrm{Cr}_{2} \mathrm{O}_{3} / \mathrm{kg}$ of concentrate DM) was supplied for each cow starting on $\mathrm{d} 1$ of the experimental period. During the $\mathrm{CH}_{4}$ measurement period grab samples of feces (ca. $300 \mathrm{~g}$ ) were collected daily during milking and stored at $-20^{\circ} \mathrm{C}$. Prior to freeze drying, the samples were pooled per cow and mixed and a subsample was taken.

The BW of cows was taken on the first (d 13) and the last day (d 17) of the measurement period. The animals in the chamber were tethered in individual stalls complete with slatted floor fitted for collection of the manure (mixture of feces and urine). For com- 
plete N-balance determination, the manure produced by the 2 cows in a chamber during the 5 -d period was quantitatively collected, weighed, mixed thoroughly, subsampled, and stored at $-20^{\circ} \mathrm{C}$ pending analysis. Also, $\mathrm{N}$ volatilized in the form of ammonia that may result from mixing of feces and urine was obtained from samples of condensed water (i.e., collected from the heat exchanger) and $25 \%$ sulfuric acid solution wt/wt (i.e., through which the outflowing air was led to trap aerial ammonia) of each chamber.

\section{Milk Yield and Milk Composition}

Cows were milked twice daily (0600 and $1600 \mathrm{~h}$ ), and milk yield was recorded during the $5 \mathrm{~d}$ of $\mathrm{CH}_{4}$ measurement period. During each milking samples were collected in duplicate. Morning and afternoon samples were collected separately into tubes containing sodium azide and stored no longer than $4 \mathrm{~d}$ at $+4^{\circ} \mathrm{C}$ pending fat-, $\mathrm{CP}_{-}$, and lactose-contents analysis and determination of SCC concentration. The second sample was pooled per cow based on a weight basis proportional to milk yield ( $5 \mathrm{~g} / \mathrm{kg}$ of milk) and stored at $-20^{\circ} \mathrm{C}$ until analysis for urea, energy, and $\mathrm{N}$ content.

\section{In Situ Rumen Degradation of Diets}

Ruminal degradability of starch, $\mathrm{OM}$, and $\mathrm{N}$ in concentrate was determined in a separate experiment using 3 rumen-cannulated lactating Holstein-Friesian dairy cows. The cows were $387.0 \pm 7.8 \mathrm{DIM}$ and producing $22.8 \pm 3.9 \mathrm{~kg} / \mathrm{d}$ of milk. Cows were fed ad libitum a mixed ration of $50 \%$ grass silage $(\mathrm{CP}, 104 \mathrm{~g} / \mathrm{kg}$ of DM; $\mathrm{NDF}, 516 \mathrm{~g} / \mathrm{kg}$ of DM) and $50 \%$ maize silage (CP, 72 $\mathrm{g} / \mathrm{kg}$ of DM; NDF, $397 \mathrm{~g} / \mathrm{kg}$ of DM, starch, $374 \mathrm{~g} /$ $\mathrm{kg}$ of DM) and a commercial concentrate $(160 \mathrm{~g} / \mathrm{kg}$ of DM starch, $200 \mathrm{~g} / \mathrm{kg}$ of DM CP, $38 \mathrm{~g} / \mathrm{kg}$ of DM crude fat, and $80 \mathrm{~g} / \mathrm{kg}$ of DM ash) according to milk production up to a maximum of $8 \mathrm{~kg} / \mathrm{d}$. Only concentrate samples were incubated in the rumen. The effective rumen degradability (ED) of OM in the grass silage was estimated by near infrared spectroscopy analysis (BLGG AgroXpertus, Wageningen, the Netherlands). Nylon bags were prepared according to the Dutch in situ protocol (Tas et al., 2006). Briefly, nylon bags with an inner size of $10 \times 8 \mathrm{~cm}$, a pore size of $40 \mu \mathrm{m}$, and porosity of 0.30 (PA 40/30, Nybolt, Switzerland) were filled with approximately $5 \mathrm{~g}$ (DM basis) of concentrate ground to pass a $3-\mathrm{mm}$ sieve. Three bags per incubation time for each concentrate were incubated for 2 , $4,6,8,12,24$, and $48 \mathrm{~h}$ in the rumen of each cow using the all-in, all-out procedure. After incubation, bags were immediately placed in ice water for approximately $5 \mathrm{~min}$ to stop fermentation, and rinsed with tap water. The bags were then washed in a washing machine (AEG Turnamat SL, Nuremberg, Germany) for $40 \mathrm{~min}$ in cold water (gentle wool-wash program without centrifuging) and freeze-dried. Dried samples were weighed, pooled to one sample per incubation time per cow; ground through a 1-mm sieve (Peppink 100AN, Olst, the Netherlands); and analyzed for DM, ash, N, and starch.

To determine the rumen degradation characteristics of $\mathrm{OM}, \mathrm{N}$, and starch in the concentrates, residues per incubation time per cow were fitted to a first-order nonlinear model: $Y(t)=U+D \times \mathrm{e}^{-k_{d} \times t}$, where $Y(t)=$ proportion of total residue present at time $t(\mathrm{~g} / \mathrm{kg}) ; U$ $=$ the truly undegradable fraction $(\mathrm{g} / \mathrm{kg}$; for $\mathrm{OM}$ and $\mathrm{N}$ only); $D=$ the potentially degradable fraction $(\mathrm{g} / \mathrm{kg}) ; t$ $=$ time of incubation $(\mathrm{h})$; and $k_{d}=$ the fractional rate of degradation of the $D$ fraction (per hour). The NLIN procedure of SAS (SAS Institute Inc., 2010) was used to estimate the parameter values, with $D, U$, and $k_{d}$ constrained to be positive. The ED of starch, OM, and $\mathrm{N}$ in the concentrates was calculated as described by Ørskov and McDonald (1979) using the formula ED = $W+\left(D \times k_{d}\right) /\left(k_{d}+k_{p}\right)$ and assuming a fractional ruminal outflow rate $\left(k_{p}\right)$ of 0.06 per hour for concentrates (Tamminga et al., 1994). The washout $(W)$ fraction $(\mathrm{g} /$ $\mathrm{kg}$ ), which is assumed to be rapidly degradable, was calculated as 1,000 - D - U. The estimated rumenfermentable OM (eRFOM) in the total mixed diets was calculated using the ED of $\mathrm{OM}$ of concentrates obtained from the rumen incubations and the estimated $\mathrm{ED}$ of $\mathrm{OM}$ of grass silage, by taking into account the OM content of grass silage and each concentrate, and the proportion of these diet ingredients.

\section{Analytical Procedures}

All samples of feeds, orts, feces, and manure were freeze-dried and ground to pass through a 1-mm sieve using a Wiley mill (Peppink 100AN) before analysis, except for $\mathrm{N}$ analysis in manure and $\mathrm{NH}_{3}-\mathrm{N}$ analysis in the silage for which fresh samples were used. Feed and feces samples were analyzed for DM (ISO 6496, 1999), ash (ISO 5984, 2002), N (ISO 5983, 2005), crude fat (ISO 6492, 1999), starch (ISO 15914, 2004), and gross energy (GE; ISO 9831, 1998). Crude protein content was calculated as $\mathrm{N} \times 6.25$. Neutral detergent fiber was analyzed according to Van Soest et al. (1991) after pretreatment with amylase. Acid detergent fiber and ADL were determined according to Van Soest (1973). Determination of sugar content in the feed was based on the method described by Van Vuuren et al. (1993). Concentrate and feces samples were analyzed for chromium using atomic absorption spectrophotometry (Williams et al., 1962). Milk protein, fat, and lactose contents 
and SCC concentration were determined according to ISO 9622 (1999) at VVB (VVB, Doetinchem, the Netherlands), and milk urea was determined using the $\mathrm{pH}$ difference technique (ISO 14637, 2004).

For determination of the concentration of VFA, the frozen ruminal fluid samples were thawed and centrifuged at $10,000 \times g$ for $10 \mathrm{~min}$ at $4^{\circ} \mathrm{C}$. The supernatant was transferred to a gas-chromatography vial for analysis of VFA concentration using gas chromatography (Fisons HRGC MEGA2, CI instruments, Milan, Italy) according to the method described by Taweel et al. (2005).

\section{Statistical Analysis}

In general, statistical analysis were carried out by ANOVA using the PROC MIXED procedure in SAS (SAS Institute Inc., 2010) using various models. The data for 2 cows fed on the diet consisting of $270 \mathrm{~g}$ of rapidly fermentable starch per kilogram of concentrate DM in one respiration chamber had to be excluded from all analysis because of malfunctioning of the chamber and unreliable data. Daily data were averaged per experimental unit per period before statistical analysis. Cow was considered as the experimental unit for all measurements except for $\mathrm{CH}_{4}$-production parameters and $\mathrm{N}$ and energy balance traits, for which a pair of cows housed in the same respiration chamber was considered to be the experimental unit. For $\mathrm{CH}_{4}$-production parameters and $\mathrm{N}$ and energy balance traits, the model included the fixed effects of respiration chamber, starch source, level of starch, and source $\times$ level interaction, and a random effect of period. Block was not included in the model, because the 2 cows housed within the same chamber originated from different blocks. For DMI, fecal digestibility, and milk characteristics the model included respiration chamber, block, starch source, level of starch, and source $\times$ level interaction as fixed effects, and period as a random factor. For all analysis, the fixed effect of respiration chamber was initially included in the model but was removed from the model because it was not significant. Because of unequal variances, the Kenward-Roger option was used to estimate the denominator degrees of freedom. Autoregressive 1, compound symmetry, and unstructured covariance structures were tested for each analysis. Depending on the characteristics of analysis, the covariance structure with the lowest Akaike's information criterion was selected (Littell et al., 1998), which in most cases was the compound-symmetry covariance structure.

Similarly, data for ruminal $\mathrm{pH}$ and VFA concentration were analyzed using the PROC MIXED procedure in SAS with block, starch source, level of starch, time, source $\times$ level, source $\times$ time, and level $\times$ time interactions as fixed effects and cow as a random effect using the repeated measures procedure with time as repeated measures. The relationship between measurements was assumed to be linear. The covariance structure was defined in the model as being spatial power for unequally spaced measurement times.

Data on in situ rumen degradation of concentrates and diets were similarly analyzed using the PROC MIXED procedure in SAS with starch source, level of starch, and source $\times$ level interaction as fixed effects and cow as random effect.

All results are reported as least squares means. Significance of effect was declared at $P \leq 0.05$ and trends at $0.05<P \leq 0.10$.

\section{RESULTS}

\section{Chemical Composition of Concentrates and Diets}

The chemical composition of concentrates, grass silage, and total mixed diets is presented in Table 1 and Table 2. The nutrient composition in the concentrates had slight differences, in particular in starch content. Starch content in concentrates with rapidly fermentable (R) starch had a $26 \mathrm{~g} / \mathrm{kg}$ of DM higher starch content than concentrates with slowly fermentable (S) starch, resulting in an average $11 \mathrm{~g} / \mathrm{kg}$ of DM higher starch content in total mixed diets containing $\mathrm{R}$ starch compared with S starch. The analyzed GE content of grass silage was somewhat higher than expected and higher than that of concentrates. Because the proportion of grass silage in the total diet did not differ between treatments, the high GE content of the silage did not affect differences between treatments.

\section{In Situ Rumen-Degradation Characteristics}

Starch source affected all degradation characteristics of starch, N, and OM (Table 3). Concentrates composed of $\mathrm{R}$ starch had about 3 times higher $(P<0.001) k_{d}$ of starch than concentrates based on $\mathrm{S}$ starch (average $k_{d}$ $=0.155 / \mathrm{h}$ vs. $0.054 / \mathrm{h}$, respectively) and a much higher $W$ fraction (average 315 vs. $64 \mathrm{~g} / \mathrm{kg}$, respectively; $P<$ 0.001), leading to a $59 \%$ higher ED of starch. A significant interaction between source and level of starch indicated that the effect of source of starch on $W, D$, $k_{d}$, and ED of starch was more pronounced with low starch levels than with high starch levels in the concentrate. The effects of starch resulted in a lower ED of $\mathrm{OM}$ and $\mathrm{N}$ for $\mathrm{S}$ starch- compared with $\mathrm{R}$ starch-based concentrates and a higher ED with $\mathrm{H}$ compared with L. These effects were less pronounced with L compared with $\mathrm{H}$ for $\mathrm{ED}$ of starch. The calculated eRFOM in 
Table 2. Analyzed chemical composition of grass silage and calculated chemical composition of total mixed diets $(\mathrm{g} / \mathrm{kg}$ of DM, unless otherwise stated)

\begin{tabular}{|c|c|c|c|c|c|}
\hline \multirow[b]{2}{*}{ Item } & \multirow[b]{2}{*}{ Grass silage } & \multicolumn{4}{|c|}{ Total mixed $\operatorname{diet}^{1}$} \\
\hline & & SL & $\mathrm{SH}$ & $\mathrm{RL}$ & $\mathrm{RH}$ \\
\hline $\mathrm{DM}$ (g/kg of product as fed) & 512 & 664 & 666 & 663 & 659 \\
\hline Ash & 88 & 74 & 72 & 71 & 72 \\
\hline $\mathrm{CP}$ & 148 & 156 & 157 & 156 & 163 \\
\hline NDF & 528 & 441 & 385 & 440 & 378 \\
\hline $\mathrm{ADF}$ & 296 & 252 & 214 & 250 & 210 \\
\hline ADL & 20 & 29 & 21 & 29 & 21 \\
\hline Crude fat & 38 & 40 & 36 & 42 & 39 \\
\hline Starch & $\mathrm{NA}^{2}$ & 110 & 207 & 121 & 217 \\
\hline Sugar & 79 & 62 & 56 & 61 & 56 \\
\hline Gross energy (MJ/kg of DM) & 19.1 & 18.8 & 18.8 & 18.9 & 18.7 \\
\hline
\end{tabular}

${ }^{1}$ Calculated based on analyzed chemical composition of grass silage and concentrate and mixed at a 60:40 ratio (on DM basis); $\mathrm{SL}=$ diet containing $270 \mathrm{~g}$ of slowly fermentable starch per kilogram of concentrate DM; SH $=$ diet containing $530 \mathrm{~g}$ of slowly fermentable starch per kilogram of concentrate DM; RL = diet containing $270 \mathrm{~g}$ of rapidly fermentable starch per kilogram of concentrate DM; $\mathrm{RH}=$ diet containing $530 \mathrm{~g}$ of rapidly fermentable starch per kilogram of concentrate DM.

${ }^{2}$ Not analyzed.

a total mixed diet was lower for $\mathrm{S}$ starch than for $\mathrm{R}$ starch, and lower for $\mathrm{L}$ starch than for $\mathrm{H}$ starch $(P$ $<0.001$ ), but a significant interaction between source and level of starch indicated that the effects are not additive.

\section{Ruminal $\mathrm{pH}$ and Concentration of VFA}

The effects of source and level of starch in the diet on rumen $\mathrm{pH}$, VFA concentration, and VFA molar proportions are presented in Table 4. Mean ruminal $\mathrm{pH}$ was not affected by either starch rate of fermentation or by level of starch in the diets, whereas total VFA concentration was higher for diets based on $\mathrm{R}$ starch than on $\mathrm{S}$ starch (109.2 vs. $97.5 \mathrm{mM}, P=0.002)$. Both source and level of starch in the diet did not affect VFA molar proportions, except for higher propionate proportions $(P=$ $0.046)$ and a trend for lower isobutyrate proportions $(P$ $=0.051)$ and acetate:propionate ratio $(P=0.054)$ with the $\mathrm{R}$ starch-based diets compared with the $\mathrm{S}$ starchbased diets. On average for all dietary treatments, the $\mathrm{pH}$ decreased from the prefeeding value of 6.73 to 6.41 and 6.33 at 3 and $4 \mathrm{~h}$ after a.m. feeding, respectively (Figure 1). Rumen total VFA concentrations (Figure 2) and acetate:propionate ratio (Figure 3) varied with time of sampling relative to a.m. feeding. The interactions between time and source or level of starch were not significant, except for rumen $\mathrm{pH}(P<0.001)$.

\section{Feed Intake and Nutrient Digestibility}

Dry matter intake and apparent total-tract nutrient digestibility are presented in Table 5. Dry matter intake was $0.8 \mathrm{~kg} / \mathrm{d}$ lower with the high level of starch
$(P=0.022)$ but was unaffected by source of starch in the diet. Dry matter intake in the chambers (mean $19.0 \mathrm{~kg} / \mathrm{d}$ ) did not differ from DMI during the last 3 $\mathrm{d}$ of the adaptation period in the tie-stalls (mean 18.9 $\mathrm{kg} / \mathrm{d}$ ). Apparent total-tract digestibility of NDF and $\mathrm{CP}$ was not affected by dietary treatments. However, for both DM and OM digestibility as well as for crude fat and GE digestibility, significant interactions existed between source and level of starch in the diet, showing a higher digestibility with increased starch level of $\mathrm{R}$ starch but a lower digestibility with increased starch level for S starch. Diets based on R starch had a $1.7 \%$ higher starch digestibility compared with S starchbased diets $(P=0.006)$. The level of starch in the diet had no effect on starch digestibility.

\section{Milk Yield and Milk Composition}

Daily milk yield (average $24.0 \mathrm{~kg} / \mathrm{d}$ ) and content of fat $(5.05 \%)$, protein $(3.64 \%)$, lactose $(4.53 \%)$, and milk urea $(3.51 \mathrm{mmol} / \mathrm{L})$ were not influenced by either source or level of starch in diet (Table 6). Similarly SCC concentration was not affected by either source or level of starch in the diet. The FPCM and milk fat yield showed a tendency $(P=0.092$ and $P=0.077$, respectively) to be higher for diets containing a low level of starch. Milk protein yield showed a tendency $(P=0.088)$ to be higher for cows fed diets based on $\mathrm{R}$ starch compared with $\mathrm{S}$ starch.

\section{Dietary Treatments and Methane Production}

Daily $\mathrm{CH}_{4}$ production was not affected by source of starch but was higher at low starch levels than at a high 
Table 3. In situ rumen degradation characteristics of the concentrates used in the experiment and estimated effective rumen degradability of $\mathrm{OM}$ in the total mixed diet

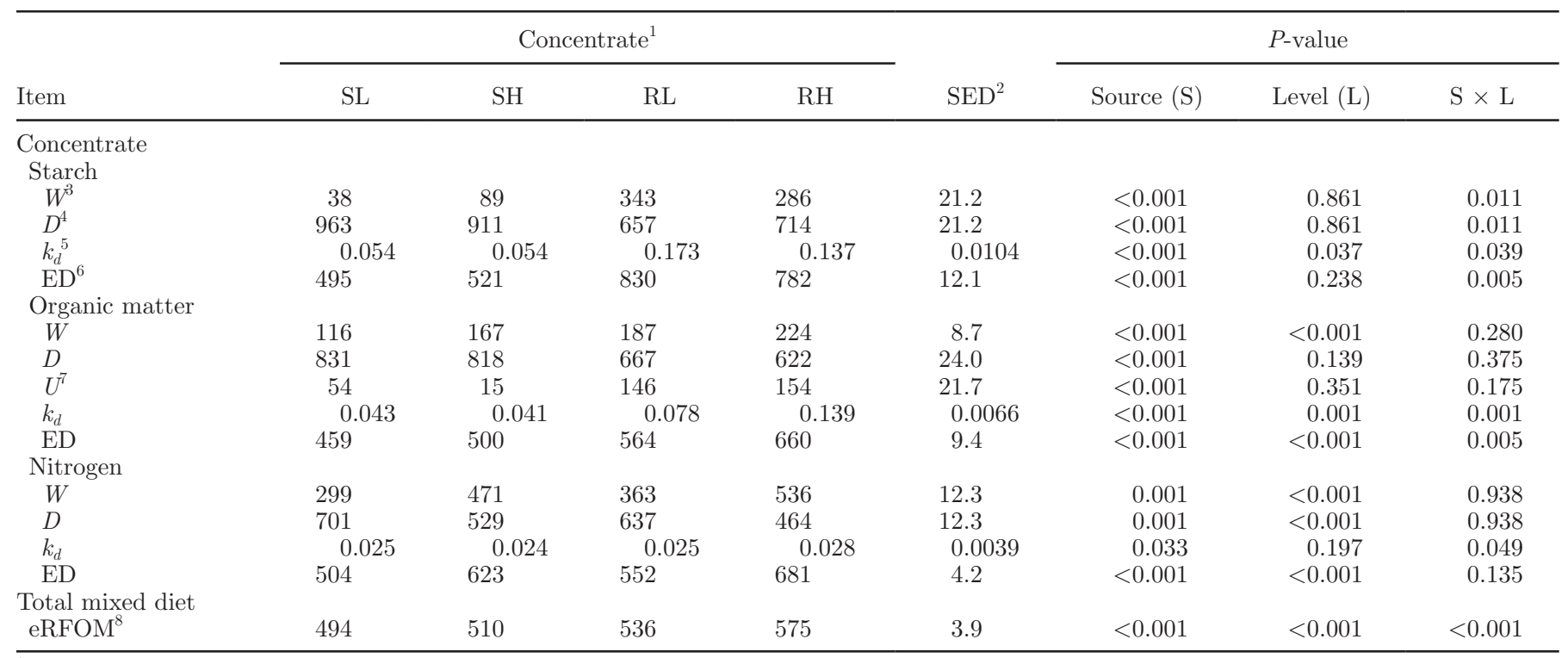

${ }^{1} \mathrm{SL}=$ concentrate containing $270 \mathrm{~g}$ of slowly fermentable starch per kilogram of concentrate DM; $\mathrm{SH}=$ concentrate containing $530 \mathrm{~g}$ of slowly fermentable starch per kilogram of concentrate DM; RL = concentrate containing $270 \mathrm{~g}$ of rapidly fermentable starch per kilogram of concentrate $\mathrm{DM} ; \mathrm{RH}=$ concentrate containing $530 \mathrm{~g}$ of rapidly fermentable starch per kilogram of concentrate DM.

${ }^{2} \mathrm{SED}=\mathrm{SE}$ of the difference of means.

${ }^{3} \mathrm{~W}=$ washable fraction $(\mathrm{g} / \mathrm{kg}$ of respective nutrient).

${ }^{4} D=$ potentially degradable fraction (g/kg of respective nutrient).

${ }^{5} k_{d}=$ fractional degradation rate (per hour) of potential degradable fraction.

${ }^{6} \mathrm{ED}=$ effective rumen degradability ( $\mathrm{g} / \mathrm{kg}$ of respective nutrient).

${ }^{7} \mathrm{U}=$ undegradable fraction ( $\mathrm{g} / \mathrm{kg}$ of respective nutrient) and estimated to be zero for starch and $\mathrm{N}$.

${ }^{8} \mathrm{eRFOM}=$ estimated rumen-fermentable OM in the total mixed diets $(\mathrm{g} / \mathrm{kg}$ of OM$)$ was calculated using the ED of OM of concentrates obtained from the rumen incubations and the estimated ED of OM in the grass silage estimated by near-infrared spectroscopy analysis.

starch levels (432 vs. $399 \mathrm{~g} / \mathrm{d}$, respectively; $P=0.017$; Table 7). Methane production per kilogram of milk, per kilogram of FPCM, per kilogram of DMI, per kilogram of digested DM, and as percentage of GE intake was not influenced by dietary treatments. However, $\mathrm{CH}_{4}$ expressed per kilogram of eRFOM was higher for diets based on S starch than R starch (47.4 vs. $42.6 \mathrm{~g} / \mathrm{kg}$ of eRFOM, respectively; $P<0.001)$, and for diets based on $\mathrm{L}$ than $\mathrm{H}(46.9$ vs. $43.1 \mathrm{~g} / \mathrm{kg}$ of eRFOM, respectively; $P=0.002)$.

Table 4. Rumen fluid pH and concentration of VFA of lactating dairy cows fed diets that differed in starch rate of fermentation and level of inclusion in concentrate

\begin{tabular}{|c|c|c|c|c|c|c|c|c|}
\hline Item & \multicolumn{4}{|c|}{$\operatorname{Diet}^{1}$} & $\mathrm{SED}^{2}$ & \multicolumn{3}{|c|}{$P$-value } \\
\hline Rumen pH & 6.53 & 6.49 & 6.51 & 6.53 & 0.088 & 0.872 & 0.889 & 0.650 \\
\hline Acetate (A) & 68.3 & 69.1 & 68.6 & 67.9 & 0.55 & 0.272 & 0.859 & 0.069 \\
\hline Propionate $(\mathrm{P})$ & 15.9 & 15.6 & 16.2 & 16.8 & 0.46 & 0.046 & 0.684 & 0.172 \\
\hline Isovalerate & 1.69 & 1.64 & 1.82 & 1.29 & 0.311 & 0.637 & 0.215 & 0.281 \\
\hline $\mathrm{A}: \mathrm{P}$ & 4.31 & 4.45 & 4.27 & 4.06 & 0.146 & 0.054 & 0.725 & 0.107 \\
\hline
\end{tabular}

${ }^{1} \mathrm{n}=4$ for all diets except for RL for which $\mathrm{n}=3$. SL = diet containing $270 \mathrm{~g}$ of slowly fermentable starch per kilogram of concentrate DM; SH $=$ diet containing $530 \mathrm{~g}$ of slowly fermentable starch per kilogram of concentrate DM; RL = diet containing $270 \mathrm{~g}$ of rapidly fermentable starch per kilogram of concentrate $\mathrm{DM}$; $\mathrm{RH}=$ diet containing $530 \mathrm{~g}$ of rapidly fermentable starch per kilogram of concentrate DM.

${ }^{2} \mathrm{SED}=\mathrm{SE}$ of the difference of means. 


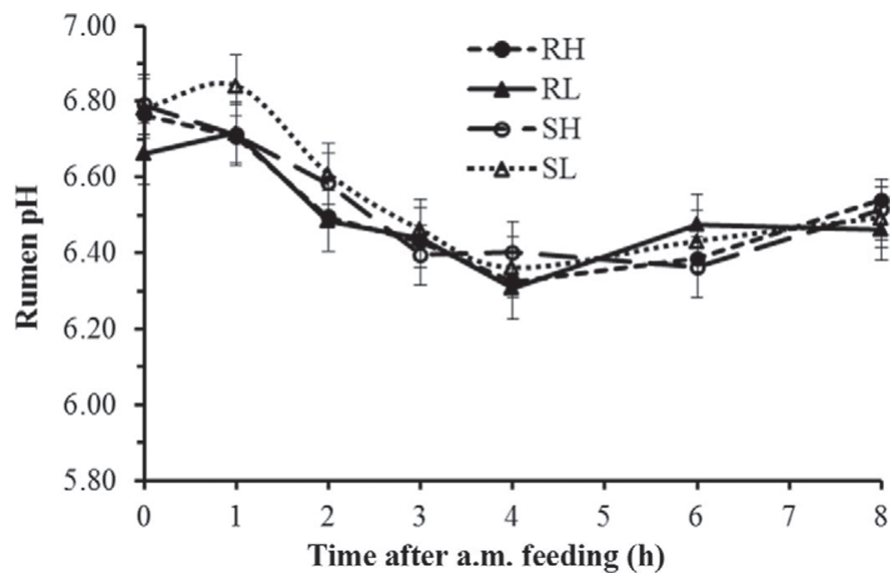

Figure 1. Effects of source and level of starch in the diet of lactating dairy cows on rumen $\mathrm{pH}$ as a function of time after a.m. feeding. $\mathrm{SL}=$ diet containing $270 \mathrm{~g}$ of slowly fermentable starch per kilogram of concentrate DM; SH = diet containing $530 \mathrm{~g}$ of slowly fermentable starch per kilogram of concentrate DM; RL = diet containing $270 \mathrm{~g}$ of rapidly fermentable starch per kilogram of concentrate $\mathrm{DM} ; \mathrm{RH}=$ diet containing $530 \mathrm{~g}$ of rapidly fermentable starch per kilogram of concentrate DM. Effect of time $(P<0.001)$ and interactions of source of starch with time $(P=0.143)$ and level of starch with time $(P=$ 0.027). Error bars represent the standard error of the difference.

\section{Nitrogen and Energy Balance}

Nitrogen and energy balance data are presented in Table 8 . Daily $\mathrm{N}$ intake was not affected by source and level of starch. Total N excretion in manure (feces and

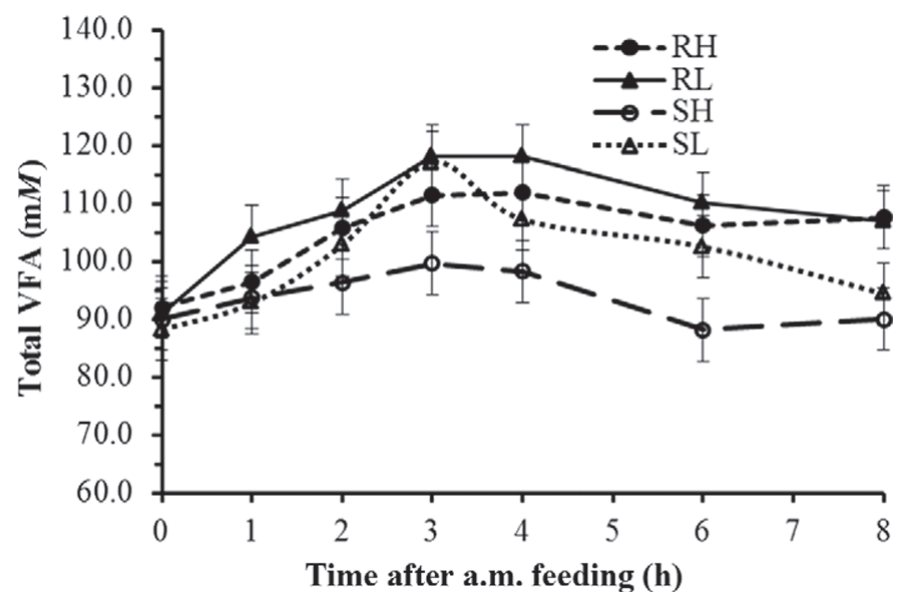

Figure 2. Effects of source and level of starch in the diet of lactating dairy cows on rumen total VFA concentration as a function of time after a.m. feeding. SL $=$ diet containing $270 \mathrm{~g}$ of slowly fermentable starch per kilogram of concentrate DM; SH = diet containing $530 \mathrm{~g}$ of slowly fermentable starch per kilogram of concentrate DM; RL = diet containing $270 \mathrm{~g}$ of rapidly fermentable starch per kilogram of concentrate $\mathrm{DM} ; \mathrm{RH}=$ diet containing $530 \mathrm{~g}$ of rapidly fermentable starch per kilogram of concentrate DM. Effect of time $(P<0.001)$ and interactions of source of starch with time $(P=0.725)$ and level of starch with time $(P=0.592)$. Error bars represent the standard error of the difference.

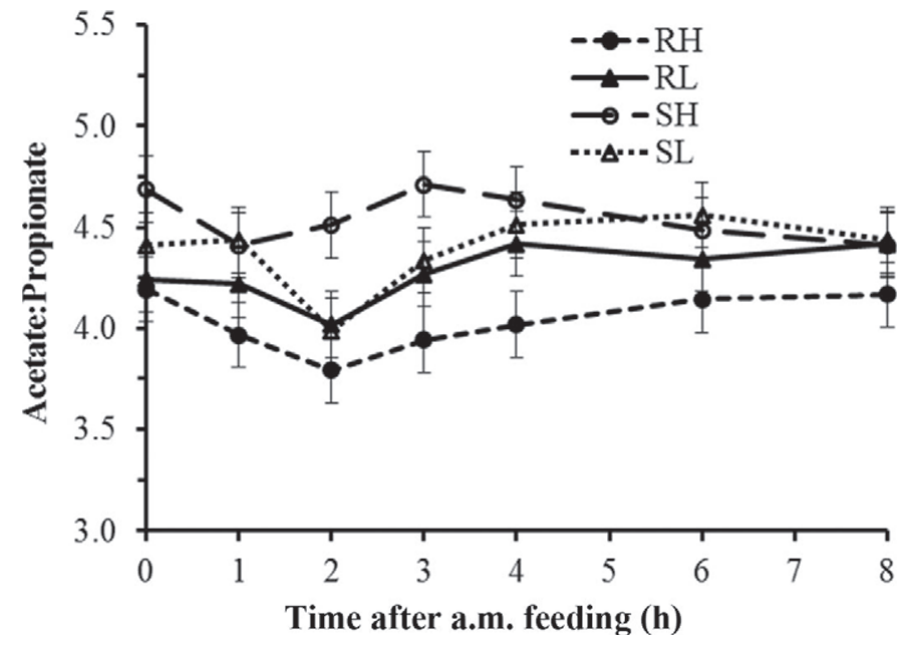

Figure 3. Effects of source and level of starch in the diet of lactating dairy cows on rumen acetate:propionate ratio as a function of time after a.m. feeding. SL = diet containing $270 \mathrm{~g}$ of slowly fermentable starch per kilogram of concentrate DM; SH = diet containing $530 \mathrm{~g}$ of slowly fermentable starch per kilogram of concentrate DM; RL = diet containing $270 \mathrm{~g}$ of rapidly fermentable starch per kilogram of concentrate $\mathrm{DM} ; \mathrm{RH}=$ diet containing $530 \mathrm{~g}$ of rapidly fermentable starch per kilogram of concentrate DM. Effect of time $(P=0.002)$ and interactions of source of starch with time $(P=0.928)$ and level of starch with time $(P=0.147)$.Error bars represent the standard error of the difference.

urine mixture) tended $(P=0.064)$ to be higher with diets based on $\mathrm{R}$ starch as compared with $\mathrm{S}$ starch. Diets based on $\mathrm{R}$ starch showed a tendency $(P=0.060)$ of higher secretion of $\mathrm{N}$ in milk as compared with diets based on $\mathrm{S}$ starch. There was a tendency $(P=0.088)$ of a lower secretion of $\mathrm{N}$ in milk for $\mathrm{H}$ compared with $\mathrm{L}$ in the diet. Nitrogen retention was not affected by level or source of starch in the diet. Also, no significant differences were observed for GE intake, ME intake, heat production, milk energy output, and total energy retention (all expressed per unit metabolic BW) between treatments.

\section{DISCUSSION}

This study investigated the effects of starch varying in rate of fermentation and level of inclusion in the diet in exchange for fiber on $\mathrm{CH}_{4}$ production in lactating dairy cows. Our hypothesis was that increasing the inclusion of ruminally fermentable starch in the diet at the expense of fiber would increase propionate in the rumen, and that decreasing rate of fermentation of starch would shift digestion from the rumen to the small intestine, both expected to decrease $\mathrm{CH}_{4}$ production expressed per unit of feed or milk. Rumen propionate molar proportion was higher with $\mathrm{R}$ starch $(16.5 \mathrm{~mol} / 100 \mathrm{~mol})$ than with $\mathrm{S}$ starch $(15.8 \mathrm{~mol} / 100$ mol), but level of starch did not influence rumen molar 
Table 5. Dry matter intake and apparent total-tract digestibility of nutrients in lactating dairy cows fed diets that differed in starch rate of fermentation and level of inclusion in concentrate

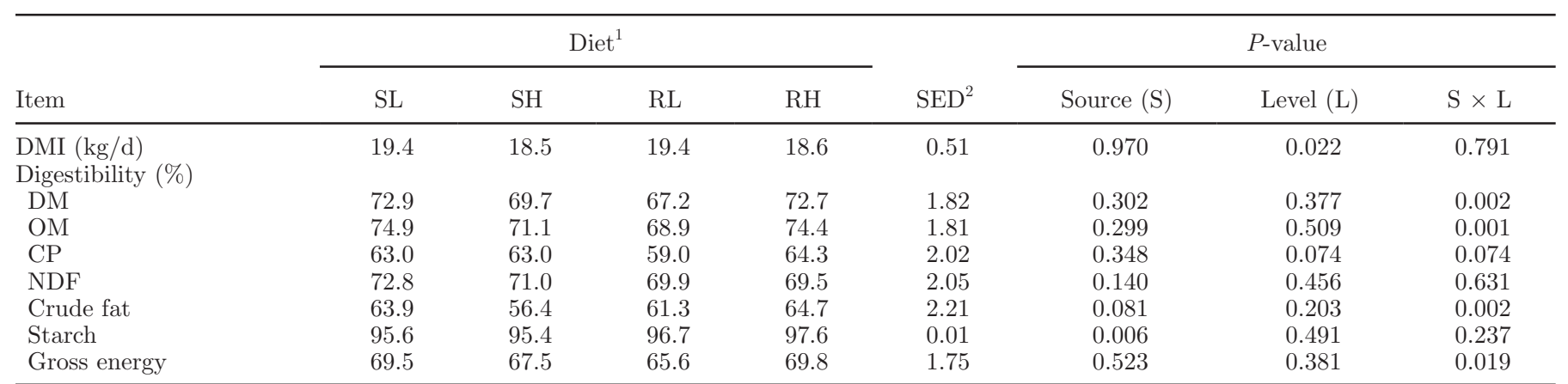

${ }^{1} \mathrm{n}=10$ for SL, SH, and RH, and $\mathrm{n}=8$ for RL. SL = diet containing $270 \mathrm{~g}$ of slowly fermentable starch per kilogram of concentrate DM; SH = diet containing $530 \mathrm{~g}$ of slowly fermentable starch per kilogram of concentrate DM; RL = diet containing $270 \mathrm{~g}$ of rapidly fermentable starch per kilogram of concentrate $\mathrm{DM}$; $\mathrm{RH}=$ diet containing $530 \mathrm{~g}$ of rapidly fermentable starch per kilogram of concentrate DM.

${ }^{2} \mathrm{SED}=\mathrm{SE}$ of the difference of means.

Table 6. Milk yield and milk composition of dairy cows fed diets that differed in starch rate of fermentation and level of inclusion in concentrate

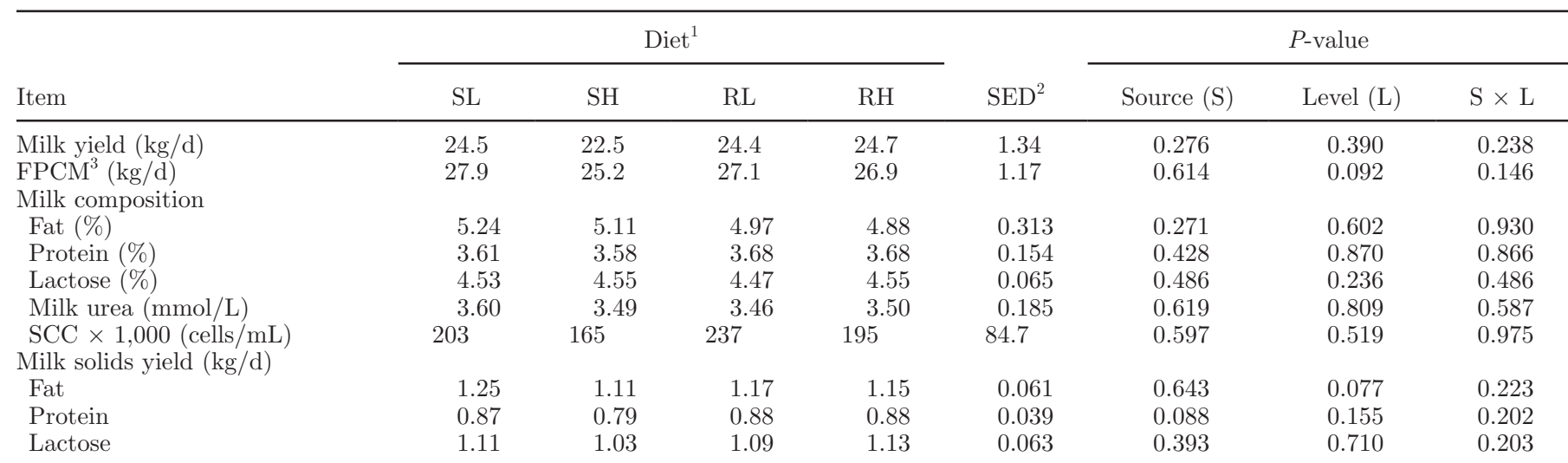

${ }^{1} \mathrm{n}=10$ for SL, SH, and RH, and $\mathrm{n}=8$ for RL. SL = diet containing $270 \mathrm{~g}$ of slowly fermentable starch per kilogram of concentrate DM; SH $=$ diet containing $530 \mathrm{~g}$ of slowly fermentable starch per kilogram of concentrate DM; RL = diet containing $270 \mathrm{~g}$ of rapidly fermentable starch per kilogram of concentrate $\mathrm{DM}$; $\mathrm{RH}=$ diet containing $530 \mathrm{~g}$ of rapidly fermentable starch per kilogram of concentrate DM.

${ }^{2} \mathrm{SED}=\mathrm{SE}$ of the difference of means.

${ }^{3}$ Fat- and protein-corrected milk $=[0.337+0.116 \times$ fat $(\%)+0.06 \times$ protein $(\%)] \times$ milk yield $(\mathrm{kg} / \mathrm{d})$.

Table 7. Methane $\left(\mathrm{CH}_{4}\right)$ production of lactating dairy cows fed diets that differed in starch rate of fermentation and level of inclusion in concentrate

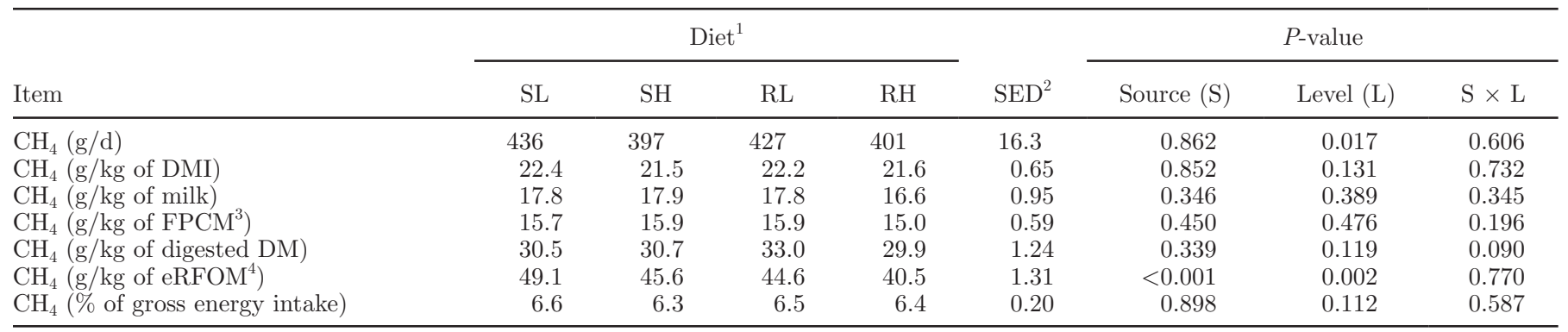

${ }^{1} \mathrm{n}=5$ for SL, SH, and RH, and $\mathrm{n}=4$ for RL. SL = diet containing $270 \mathrm{~g}$ of slowly fermentable starch per kilogram of concentrate DM; SH $=$ diet containing $530 \mathrm{~g}$ of slowly fermentable starch per kilogram of concentrate DM; RL = diet containing $270 \mathrm{~g}$ of rapidly fermentable starch per kilogram of concentrate DM; RH = diet containing $530 \mathrm{~g}$ of rapidly fermentable starch per kilogram of concentrate DM.

${ }^{2} \mathrm{SED}=\mathrm{SE}$ of the difference of means.

${ }^{3} \mathrm{FPCM}=$ fat- and protein-corrected milk.

${ }^{4} \mathrm{eRFOM}=$ estimated rumen-fermentable OM. 


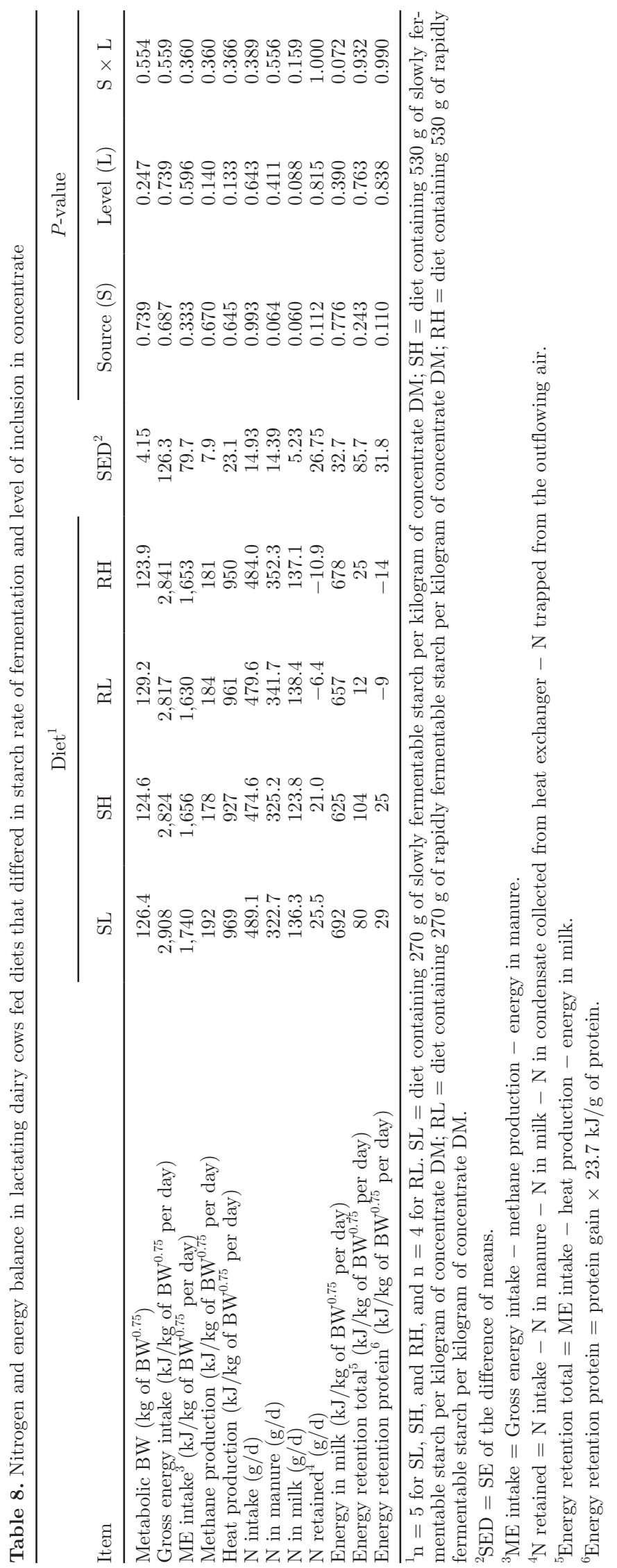

proportion of propionate. The in situ ruminal starch degradation rates of the 2 starch sources differed almost by a factor of 3 ( 0.054 vs. 0.155 per hour; $\mathrm{S}$ vs. R starch), and the estimated amount of rumen-degraded starch was 508 versus $806 \mathrm{~g} / \mathrm{kg}$ of dietary starch for $\mathrm{S}$ versus $\mathrm{R}$ starch. The in situ characteristics were in agreement with our aim to select the starch sources that represent a wide range of starch fermentation rate. Methane expressed per unit of eRFOM was 10\% lower for $\mathrm{R}$ than $\mathrm{S}$ starch and $8 \%$ lower for $\mathrm{H}$ - than L-based diets. However, $\mathrm{CH}_{4}$ production per kilogram of milk, per kilogram of FPCM, per kilogram of DMI, or as percentage of GE intake was not influenced by dietary treatments.

\section{Effects on Ruminal $\mathrm{pH}$ and Concentration of VFA}

In the current study, the contrast in starch content of the diet was achieved by replacement of fiber-rich beet pulp and palm kernel expeller with corn grain. Much of the nonfiber carbohydrate in beet pulp is pectin and has a tendency for a rumen fermentation profile with more acetate and butyrate (Voelker and Allen, 2003a). Similarly, in a study in which barley was partially substituted with beet pulp in the concentrate, molar proportion of acetate increased and that of propionate and total VFA concentration in the rumen contents decreased (Bodas et al., 2007). Bannink et al. (2006) analyzed VFA data from 182 diets and found higher molar proportions of propionic acid to occur upon fermentation of starch compared with fermentation of cellulose or hemicellulose. In contrast with these findings, rumen acetate and propionate molar proportions were not affected by level of starch, although the source of starch (R vs. S) did significantly affect propionate molar proportion. The relatively high mean daily rumen $\mathrm{pH}$ recorded with all treatments may have been the reason for the absence of a substantial response in propionic acid production. Bannink et al. (2008) estimated that with elevated rumen $\mathrm{pH}$ the fraction of starch fermented to propionic acid rather than acetic and butyric acid decreases, with the minimum reached at $\mathrm{pH}$ values above 6.5. At this $\mathrm{pH}$, the minimum fraction of starch fermented to propionic acid is just slightly higher than the fraction of cellulose or hemicellulose fermented to propionic acid on roughage-type diets (more than 50\% roughage on DM basis).

In the present study, starch content increased from on average 116 (low starch level) to 212 (high starch level) $\mathrm{g} / \mathrm{kg}$ of DM. In a study with diets containing 152, 192, 218 , and $224 \mathrm{~g} / \mathrm{kg}$ of DM of starch from oats, barley, corn, and wheat as the primary source of carbohydrate, respectively, ruminal $\mathrm{pH}$ and VFA concentrations were unaffected (Gozho and Mutsvangwa, 2008). In another 
study, substitution of beet pulp for high-moisture corn up to $243 \mathrm{~g} / \mathrm{kg}$ of DM also did not affect daily mean or minimum ruminal pH (Voelker and Allen, 2003a). In the present study, the bicarbonate added as a buffer to the high starch concentrates may have prevented a pronounced drop in rumen $\mathrm{pH}$, which is expected to increase rumen propionate proportions (Bannink et al., 2008). This may have contributed to the absence of effect of level of starch on VFA molar proportions in the rumen.

\section{Effects on DMI, Nutrient Digestibility, and Milk Production}

Cows fed $\mathrm{H}$ starch-based diets consumed less feed compared with those fed L starch-based diets, whereas source of starch did not affect DMI. The effects of source and level of starch on feed intake are inconsistent among studies reported in the literature. In agreement with our results, a reduced DMI on a high-starch concentrate diet compared with a high-NDF concentrate diet was reported by Miron et al. (2004). Conversely, in other experiments the type of carbohydrate in concentrate mixture (starch vs. cell wall constituents) in total mixed diets did not affect DMI (De Visser et al., 1990; Abrahamse et al., 2008), whereas Beckman and Weiss (2005) reported a tendency of higher DMI as NDF in the diet increased and starch decreased. Other studies reported an increased DMI by cows fed slowly fermentable corn starch compared with rapidly fermentable barley starch (Casper and Schingoethe, 1989; McCarthy et al., 1989). Intake can be affected by numerous factors such as rate of fermentation of starch and fiber, meal patterns, metabolic fuel absorbed, and ruminal patterns of fermentation and $\mathrm{pH}$ (Allen, 2000; Voelker and Allen, 2003b; Reynolds, 2006). In the present study, the $\mathrm{ED}$ of $\mathrm{OM}$ in the rumen was $13 \%$ higher for cows fed the $\mathrm{H}$ starch diet compared with $\mathrm{L}$ starch diet, and this higher ED may be associated with reduced feed intake. With high-starch diets resulting in high propionic acid production in the rumen, DMI may decrease because of the hepatic oxidation of propionate affecting feed intake (Allen et al., 2009). Propionate uptake by liver could have been altered but was not measured. The supply could have been changed as suggested by Sutton et al. (2003).

A significantly higher apparent total-tract starch digestibility for $\mathrm{R}$ starch compared with $\mathrm{S}$ starch diets was consistent with rumen ED of starch. However, the difference in total-tract digestibility was much smaller (972 vs. $955 \mathrm{~g}$ of digested starch/kg of dietary starch; $\mathrm{R}$ vs. $\mathrm{S}$ starch-based diets) than the difference in $\mathrm{ED}$ of starch (806 vs. $508 \mathrm{~g}$ of rumen-degraded starch $/ \mathrm{kg}$ of dietary starch; R vs. S starch-based concentrates).
These values indicate that a much higher fraction of dietary starch could have been digested postruminally with $\mathrm{S}$ starch than with $\mathrm{R}$ starch diets. In agreement with our results, Gozho and Mutsvangwa (2008) reported apparent total-tract digestibility of starch in cows fed rapidly fermentable starch (oats-based diet) to be higher than in cows fed slowly fermentable starch (corn- and wheat-based diets), with no differences observed for DM, OM, and NDF digestibility. In contrast, Ferraretto et al. (2013) in their meta-analysis reported that increased dietary starch levels typically decreased ruminal and total-tract NDF digestibility when cows are fed high-starch diets. The potential for the negative associative effects of high level of fermentable starch on ruminal fiber digestionn (Firkins et al., 2001; Ferraretto et al., 2013) probably did not occur in the present study with $\mathrm{pH}$ remaining at levels high enough not to impair activity of fibrolytic bacteria.

Milk characteristics were not affected by dietary treatments. The lack of effect of starch source on milk fat in the present study is in agreement with Silveira et al. (2007), when cows were fed on wheat-, barley-, or corn-based diets. In contrast, Voelker and Allen (2003b) observed a reduced FCM yield and fat yield when lactating dairy cows were fed a diet with $18 \%$ starch compared with 27 and $31 \%$ starch diets. The tendency in higher milk protein yield observed with $\mathrm{R}$ starch-based diets may be explained by the higher eRFOM, because a rise in OM degraded may stimulate microbial protein synthesis leading to an increased absorption of amino acids in the intestine.

\section{Effects on Methane Production}

Based on differences in propionate molar proportion between treatments, a reduction in $\mathrm{CH}_{4}$ production could be expected with $\mathrm{R}$ starch compared with $\mathrm{S}$ starch, because high propionic acid levels are associated with reduced methanogenesis (Benchaar et al., 2001). However, in the present study the treatment differences for propionate molar proportion were either not present (level of starch) or rather small in size (source of starch), and this may have contributed to the absence of reduction of $\mathrm{CH}_{4}$ production per kilogram of DMI, as percentage of GE intake, or per kilogram of FPCM. In contrast, lower $\mathrm{CH}_{4}$ emissions per kilogram of DMI and as a percentage of GE for cattle fed corn compared with barley were reported by Beauchemin and McGinn (2005). Rapidly fermentable starch showed a tendency to decrease the acetate:propionate ratio. However, Martin et al. (2010) suggested that low acetate:propionate ratio and depressed $\mathrm{CH}_{4}$ production may not always be linked in high concentrate-fed animals. One of the possible explanations for the lack of relationship between 
$\mathrm{CH}_{4}$ emission and rumen VFA pattern may be due, in part, to the observation that the molar proportions of ruminal VFA do not necessarily reflect the proportion in which they are produced (Sutton et al., 2003) but rather reflect the balance between production and absorption (Dijkstra et al., 1993). This balance can be influenced by many factors including level of DMI, rumen volume, rumen absorptive capacity, and rumen $\mathrm{pH}$ (Bannink et al., 2008). Also, all dietary treatments in the current study were rather high in NDF (378 to 441 $\mathrm{g} / \mathrm{kg}$ of DM), which could promote chewing, increase salivation rate, and have contributed to rumen buffering.

In contrast to the absence of effects of dietary treatments on $\mathrm{CH}_{4}$ expressed per kilogram of DMI, $\mathrm{CH}_{4}$ production expressed per unit of eRFOM was lower for $\mathrm{R}$ than $\mathrm{S}$ starch-based diets. Such an effect was not established when $\mathrm{CH}_{4}$ production was expressed per kilogram of digested OM, or per kilogram of FPCM, in agreement with data from other studies (Mills et al., 1999; Firkins et al., 2001) because large differences in rumen ED of starch were almost completely compensated by digestion of bypass starch in the intestine. In partial agreement with our results, Hassanat et al. (2013) also found no effect on $\mathrm{CH}_{4}$ production per unit of feed intake, GE intake, and milk upon increasing dietary starch content from 170 to $228 \mathrm{~g} / \mathrm{kg}$ of DM in dairy cattle, but a further increase to $300 \mathrm{~g} / \mathrm{kg}$ of DM did reduce $\mathrm{CH}_{4}$ production. This might be an indication that higher starch levels than the highest level of $217 \mathrm{~g} / \mathrm{kg}$ of DM tested in the present study are required to reduce enteric $\mathrm{CH}_{4}$ production. In a recent review on $\mathrm{CH}_{4}$ mitigation options, Hristov et al. (2013) concluded that inclusion of starch-rich concentrates below 350 to $400 \mathrm{~g} / \mathrm{kg}$ of total diet DM influences $\mathrm{CH}_{4}$ production to a minor extent only, and $\mathrm{CH}_{4}$ emission intensity decreased particularly with levels greater than $400 \mathrm{~g} / \mathrm{kg}$ of DM. Because the starch content in the present study remained well below $400 \mathrm{~g} / \mathrm{kg}$ of DM and the contrast tested was relatively small $(100 \mathrm{~g} / \mathrm{kg}$ of $\mathrm{DM})$, the absence of starch level on $\mathrm{CH}_{4}$ production per kilogram DMI or per kilogram of FPCM is in line with these findings.

Daily $\mathrm{CH}_{4}$ production (g/d) was reduced mainly because of a higher level of starch and associated lower DMI but not due to source of starch in the diet. Similar responses in daily $\mathrm{CH}_{4}$ output were also observed by Mc Geough et al. (2010) in beef cattle fed whole-crop wheat silages with increasing dietary starch content. The $8 \%$ reduction in daily $\mathrm{CH}_{4}$ production due to high dietary level of starch observed in the present study though was for a large part due to the $4 \%$ lower DMI rather than due to the level of starch in the diet. Studies reported in literature confirm the direct relationship between $\mathrm{CH}_{4}$ production and DMI (Benchaar et al., 2001; Hristov et al., 2013).

\section{Effects on Nitrogen Balance}

For better assessment of the overall environmental impact of including different sources and levels of starch in the diet of dairy cows to reduce enteric $\mathrm{CH}_{4}$ production, emissions of other greenhouse gases such as $\mathrm{N}_{2} \mathrm{O}$ need to be accounted for. The amount and form of excreted $\mathrm{N}$ has a major effect on emissions of $\mathrm{N}_{2} \mathrm{O}$ (Dijkstra et al., 2011), and therefore in the present study we also evaluated the effects of the dietary treatments on $\mathrm{N}$ balance. Daily $\mathrm{N}$ intake and $\mathrm{N}$ retention remained unaffected by treatments. The tendency of higher $\mathrm{N}$ output in milk in cows fed $\mathrm{R}$ starch suggests that rumen-digested starch was stimulatory for milk protein synthesis and was associated with a numerical net mobilization of $\mathrm{N}$, compared with a numerical net retention of $\mathrm{N}$ with $\mathrm{S}$ starch that have been digested relatively more in the small intestine (Mills et al., 2001). In contrast, Ferraretto et al. (2013) reported a tendency of lower $\mathrm{N}$ secreted in milk in cows fed rapidly fermentable starch such as a wheat-based diet compared with cows fed slowly fermentable starch sources such as barley- or corn- based diets.

The positive $\mathrm{N}$ retention on $\mathrm{S}$ starch-based diets and the small negative $\mathrm{N}$ retention on $\mathrm{R}$ starch-based diets were not in line with the actual BW change recorded $(-0.6$ vs. $-1.3 \mathrm{~kg} / \mathrm{d}$, $\mathrm{S}$ vs. R). Inherent errors associated with $\mathrm{N}$-balance studies in lactating dairy cows (such as volatile $\mathrm{N}$ losses from manure during collection) likely result in overestimating the true $\mathrm{N}$ retention (as reviewed by Spanghero and Kowalski, 1997; Benchaar et al., 2013; Spek et al., 2013). However, in our study, all major $\mathrm{N}$ sources emitted were captured with the setup of our respiration chambers. In addition, across all treatments the $\mathrm{N}$ retention was quite close to zero, indicating no such problems of losses has occurred, whereas in a review on dairy cattle $\mathrm{N}$ balance trials, Spanghero and Kowalski (1997) calculated an average $\mathrm{N}$ balance of $39 \mathrm{~g} / \mathrm{d}$.

\section{CONCLUSIONS}

Results from this study show that both increasing the level of starch in the diet at the expense of fiber (beet pulp and palm kernel expeller) and increasing the rate of fermentation of starch did not affect $\mathrm{CH}_{4}$ emissions expressed per unit of DMI, per unit of OM digested, per unit of GE intake, or per unit of milk produced but does reduce enteric $\mathrm{CH}_{4}$ emissions of dairy cattle expressed per unit of eRFOM. Rapidly fermentable starch, but not starch level in the diet, increased the 
propionate molar proportion and tended to decrease the acetate:propionate ratio in the rumen.

\section{ACKNOWLEDGMENTS}

The authors gratefully acknowledge the Dutch Ministry of Economic Affairs (The Hague, the Netherlands), Product Board Animal Feed (Zoetermeer, the Netherlands), and the Dutch Dairy Board (Zoetermeer, the Netherlands) for providing financial support for this research project. The authors thank L. H. de Jonge (Animal Nutrition Group, Wageningen University, the Netherlands) for his assistance in conducting the in situ experiment. We also thank S. Van Laar-van Schuppen, J. M. Muylaert, T. X. H. Van der Schans - Le, and A. K. Wissink (Animal Nutrition Group, Wageningen University, the Netherlands) for their assistance in laboratory samples analysis.

\section{REFERENCES}

Abrahamse, P. A., B. Vlaeminck, S. Tamminga, and J. Dijkstra. 2008. The effect of silage and concentrate type on intake behavior, rumen function, and milk production in dairy cows in early and late lactation. J. Dairy Sci. 91:4778-4792.

Allen, M. S. 2000. Effects of diet on short-term regulation of feed intake by lactating dairy cattle. J. Dairy Sci. 83:1598-1624.

Allen, M. S., B. J. Bradford, and M. Oba. 2009. The hepatic oxidation theory of the control of feed intake and its application to ruminants. J. Anim. Sci. 87:3317-3334.

Bannink, A., J. France, S. Lopez, W. J. J. Gerrits, E. Kebreab, S. Tamminga, and J. Dijkstra. 2008. Modeling the implications of feeding strategy on rumen fermentation and functioning of the rumen wall. Anim. Feed Sci. Technol. 143:3-26.

Bannink, A., J. Kogut, J. Dijkstra, J. France, E. Kebreab, A. M. Van Vuuren, and S. Tamminga. 2006. Estimation of the stoichiometry of volatile fatty acid production in the rumen of lactating cows. J. Theor. Biol. 238:36-51.

Beauchemin, K. A., and S. M. McGinn. 2005. Methane emissions from feedlot cattle fed barley or corn diets. J. Anim. Sci. 83:653-661.

Beckman, J. L., and W. P. Weiss. 2005. Nutrient digestibility of diets with different fiber to starch ratios when fed to lactating dairy cows. J. Dairy Sci. 88:1015-1023.

Benchaar, C., F. Hassanat, R. Gervais, P. Y. Chouinard, C. Julien, H. V. Petit, and D. I. Masse. 2013. Effects of increasing amounts of corn dried distillers grains with solubles in dairy cow diets on methane production, ruminal fermentation, digestion, $\mathrm{N}$ balance, and milk production. J. Dairy Sci. 96:2413-2427.

Benchaar, C., C. Pomar, and J. Chiquette. 2001. Evaluation of dietary strategies to reduce methane production in ruminants: A modelling approach. Can. J. Anim. Sci. 81:563-574.

Bodas, R., F. J. Giraldez, S. Lopez, A. B. Rodriguez, and A. R. Mantecon. 2007. Inclusion of sugar beet pulp in cereal-based diets for fattening lambs. Small Rumin. Res. 71:250-254.

Casper, D. P., and D. J. Schingoethe. 1989. Lactational response of dairy-cows to diets varying in ruminal solubilities of carbohydrate and crude protein. J. Dairy Sci. 72:928-941.

De Visser, H., P. L. Van der Togt, and S. Tamminga. 1990. Structural and non-structural carbohydrates in concentrate supplements of silage-based dairy-cow rations. 1. Feed-intake and milk-production. Neth. J. Agric. Sci. 38:487-498.

Dijkstra, J., H. Boer, J. Van Bruchem, M. Bruining, and S. Tamminga. 1993. Absorption of volatile fatty-acids from the rumen of lactating dairy cows as influenced by volatile fatty-acid concentration, $\mathrm{pH}$ and rumen liquid volume. Br. J. Nutr. 69:385-396.
Dijkstra, J., J. L. Ellis, E. Kebreab, A. B. Strathe, S. Lopez, J. France, and A. Bannink. 2012. Ruminal pH regulation and nutritional consequences of low pH. Anim. Feed Sci. Technol. 172:22-23.

Dijkstra, J., O. Oenema, and A. Bannink. 2011. Dietary strategies to reducing $\mathrm{N}$ excretion from cattle: Implications for methane emissions. Curr. Opin. Environ. Sustain. 3:414-422.

Ferraretto, L. F., P. M. Crump, and R. D. Shaver. 2013. Effect of cereal grain type and corn grain harvesting and processing methods on intake, digestion, and milk production by dairy cows through a meta-analysis. J. Dairy Sci. 96:533-550.

Firkins, J. L., M. L. Eastridge, N. R. St-Pierre, and S. M. Noftsger 2001. Effects of grain variability and processing on starch utilization by lactating dairy cattle. J. Anim. Sci. 79:E218-E238.

Gozho, G. N., and T. Mutsvangwa. 2008. Influence of carbohydrate source on ruminal fermentation characteristics, performance, and microbial protein synthesis in dairy cows. J. Dairy Sci. 91:27262735

Hassanat, F., R. Gervais, C. Julien, D. I. Masse, A. Lettat, P. Y Chouinard, H. V. Petit, and C. Benchaar. 2013. Replacing alfalfa silage with corn silage in dairy cow diets: Effects on enteric methane production, ruminal fermentation, digestion, $\mathrm{N}$ balance, and milk production. J. Dairy Sci. 96:4553-4567.

Hristov, A. N., J. Oh, J. L. Firkins, J. Dijkstra, E. Kebreab, G. Waghorn, H. P. S. Makkar, A. T. Adesogan, W. Yang, C. Lee, P. J. Gerber, B. Henderson, and J. M. Tricarico. 2013. Mitigation of methane and nitrous oxide emissions from animal operations: I. A review of enteric methane mitigation options. J. Anim. Sci. 91:5045-5069.

IPCC (Intergovernmental Panel on Climate Change). 2007. Climate change 2007: The physical science basis. Contribution of Working Group I to the Fourth Assessment Report of the Intergovernmental Panel on Climate Change. S. Solomon, D. Qin, M. Manning, Z. Chen, M. Marquis, K. B. Averyt, M. Tignor, and H. L. Miller, ed. Cambridge Univ. Press, Cambridge, UK.

ISO 5983. 2005. Animal Feeding Stuffs. Determination of Nitrogen Content and Calculation of Crude Protein Content-Kjeldahl Method. Int. Org. Stand., Geneva, Switzerland.

ISO 5984. 2002. Animal Feeding Stuffs. Determination of Crude Ash. Int. Org. Stand., Geneva, Switzerland.

ISO 6492. 1999. Animal Feeding Stuffs. Determination of Fat Content. Int. Org. Stand., Geneva, Switzerland.

ISO 6496. 1999. Animal Feeding Stuffs. Determination of Moisture and Other Volatile Matter Content. Int. Org. Stand., Geneva, Switzerland.

ISO 9622. 1999. Whole Milk-Determination of Milk Fat, Protein and Lactose Content-Guidance on the Operation of Mid-infrared Instruments. Int. Org. Stand., Geneva, Switzerland.

ISO 9831. 1998. Animal Feeding Stuffs, Animal Products, and Feces or Urine. Determination of Gross Caloric Value-Bomb Calorimetric Method. Int. Org. Stand., Geneva, Switzerland.

ISO 14637. 2004. Milk-Determination of Urea Content-Enzymatic Method Using Difference in pH. Int. Org. Stand., Geneva, Switzerland.

ISO 15914. 2004. Animal Feeding Stuffs. Enzymatic Determination of Total Starch Content. Int. Org. Stand., Geneva, Switzerland.

Knapp, J. R., G. L. Laur, P. A. Vadas, W. P. Weiss, and J. M. Tricarico. 2014. Invited review: Enteric methane in dairy cattle production: Quantifying the opportunities and impact of reducing emissions. J. Dairy Sci. 97:3231-3261.

Koenig, K. M., K. A. Beauchemin, and L. M. Rode. 2003. Effect of grain processing and silage on microbial protein synthesis and nutrient digestibility in beef cattle fed barley-based diets. J. Anim. Sci. 81:1057-1067.

Littell, R. C., P. R. Henry, and C. B. Ammerman. 1998. Statistical analysis of repeated measures data using SAS procedures. J. Anim. Sci. 76:1216-1231.

Martin, C., D. P. Morgavi, and M. Doreau. 2010. Methane mitigation in ruminants: From microbe to the farm scale. Animal 4:351-365.

Mc Geough, E. J., P. O'Kiely, K. J. Hart, A. P. Moloney, T. M. Boland, and D. A. Kenny. 2010. Methane emissions, feed intake, performance, digestibility, and rumen fermentation of finishing beef 
cattle offered whole-crop wheat silages differing in grain content. J. Anim. Sci. 88:2703-2716.

McCarthy, R. D., T. H. Klusmeyer, J. L. Vicini, J. H. Clark, and D. R. Nelson. 1989. Effects of source of protein and carbohydrate on ruminal fermentation and passage of nutrients to the small intestine of lactating cows. J. Dairy Sci. 72:2002-2016.

Mills, J. A. N., J. Dijkstra, A. Bannink, S. B. Cammell, E. Kebreab, and J. France. 2001. A mechanistic model of whole-tract digestion and methanogenesis in the lactating dairy cow: Model development, evaluation, and application. J. Anim. Sci. 79:1584-1597.

Mills, J. A. N., J. France, and J. Dijkstra. 1999. A review of starch digestion in the lactating dairy cow and proposals for a mechanistic model: 2. Postruminal starch digestion and small intestinal glucose absorption. J. Anim. Feed Sci. 8:451-481.

Miron, J., E. Yosef, M. Nikbachat, A. Zenou, E. Maltz, I. Halachmi, and D. Ben-Ghedalia. 2004. Feeding behavior and performance of dairy cows fed pelleted non-roughage fiber byproducts. J. Dairy Sci. 87:1372-1379.

Ørskov, E. R., and I. McDonald. 1979. Estimation of protein degradation in the rumen from incubation measurements weighted according to rate of passage. J. Agric. Sci. 92:499-503.

Reynolds, C. K. 2006. Production and metabolic effects of site of starch digestion in dairy cattle. Anim. Feed Sci. Technol. 130:78-94.

SAS Institute Inc. 2010. Statistical Analysis Software. SAS/STAT 9.3 User's Guide. SAS Inst. Inc., Cary, NC.

Silveira, C., M. Oba, K. A. Beauchemin, and J. Helm. 2007. Effect of grains differing in expected ruminal fermentability on the productivity of lactating dairy cows. J. Dairy Sci. 90:2852-2859.

Spanghero, M., and Z. M. Kowalski. 1997. Critical analysis of N balance experiments with lactating cows. Livest. Prod. Sci. 52:113122.

Spek, J. W., A. Bannink, G. Gort, W. H. Hendriks, and J. Dijkstra. 2013. Interaction between dietary content of protein and sodium chloride on milk urea concentration, urinary urea excretion, renal recycling of urea, and urea transfer to the gastrointestinal tract in dairy cows. J. Dairy Sci. 96:5734-5745.

Sutton, J. D., M. S. Dhanoa, S. V. Morant, J. France, D. J. Napper, and E. Schuller. 2003. Rates of production of acetate, propionate, and butyrate in the rumen of lactating dairy cows given normal and low-roughage diets. J. Dairy Sci. 86:3620-3633.

Tamminga, S., W. M. Van Straalen, A. P. J. Subnel, R. G. M. Meijer, A. Steg, C. J. G. Wever, and M. C. Blok. 1994. The Dutch protein evaluation system - The DVE/OEB-system. Livest. Prod. Sci. 40:139-155.

Tas, B. M., H. Z. Taweel, H. J. Smit, A. Elgersma, J. Dijkstra, and S. Tamminga. 2006. Rumen degradation characteristics of perennial ryegrass cultivars during the growing season. Anim. Feed Sci. Technol. 131:102-119.

Taweel, H. Z., B. M. Tas, H. J. Smit, A. Elgersma, J. Dijkstra, and S. Tamminga. 2005. Effects of feeding perennial ryegrass with an elevated concentration of water soluble carbohydrates on intake, rumen function and performance of dairy cows. Anim. Feed Sci. Technol. 121:243-256.

Van Soest, P. J. 1973. Collaborative study of acid-detergent fiber and lignin. J. Assoc. Off. Anal. Chem. 56:781-784.

Van Soest, P. J., J. B. Robertson, and B. A. Lewis. 1991. Methods for dietary fiber, neutral detergent fiber, and nonstructural polysaccharides in relation to animal nutrition. J. Dairy Sci. 74:35833597.

Van Vuuren, A. M., C. J. Van der Koelen, H. Valk, and H. De Visser. 1993. Effects of partial replacement of ryegrass by low-protein feeds on rumen fermentation and nitrogen loss by dairy cows. J. Dairy Sci. 76:2982-2993.

Van Zijderveld, S. M., J. Dijkstra, H. B. Perdok, J. R. Newbold, and W. J. J. Gerrits. 2011a. Dietary inclusion of diallyl disulfide, yucca powder, calcium fumarate, an extruded linseed product, or medium-chain fatty acids does not affect methane production in lactating dairy cows. J. Dairy Sci. 94:3094-3104.

Van Zijderveld, S. M., B. Fonken, J. Dijkstra, W. J. J. Gerrits, H. B. Perdok, W. Fokkink, and J. R. Newbold. 2011b. Effects of a combination of feed additives on methane production, diet digestibility, and animal performance in lactating dairy cows. J. Dairy Sci. 94:1445-1454.

Verstegen, M. W. A., W. Van der Hel, H. A. Brandsma, A. M. Henken, and A. M. Bransen. 1987. The Wageningen respiration unit for animal production research: A description of the equipment and its possibilities. Pages 21-48 in Energy Metabolism in Farm Animals: Effects of Housing, Stress and Disease. M. W. A. Verstegen and A. M. Henken, ed. Martinus Nijhoff Publ., Dordrecht, the Netherlands.

Voelker, J. A., and M. S. Allen. 2003a. Pelleted beet pulp substituted for high-moisture corn: 3. Effects on ruminal fermentation, $\mathrm{pH}$, and microbial protein efficiency in lactating dairy cows. J. Dairy Sci. 86:3562-3570.

Voelker, J. A., and M. S. Allen. 2003b. Pelleted beet pulp substituted for high-moisture corn: 1. Effects on feed intake, chewing behavior, and milk production of lactating dairy cows. J. Dairy Sci. $86: 3542-3552$.

Williams, C. H., O. Iismaa, and D. J. David. 1962. Determination of chromic oxide in feces samples by atomic absorption spectrophotometry. J. Agric. Sci. 59:381-385. 